\title{
$\varepsilon B$
}

The Ernest Bloch Professorship

of Music and the Ernest Bloch Lectures

were established at the University of California

in 1962 in order to bring distinguished figures in music to the Berkeley campus from time to time.

Made possible by the Jacob and Rosa Stern Musical Fund, the professorship was founded in memory of Ernest Bloch (1880-I959), the first beneficiary of the Stern Fund and Professor of Music at Berkeley from 1940 to 1952.

THE ERNEST BLOCH PROFESSORS

\begin{tabular}{|c|c|c|c|}
\hline I964 & Ralph Kirkpatrick & I993 & Susan McClary \\
\hline $1965-66$ & Winton Dean & I994-95 & Wye J. Allanbrook \\
\hline $1966-67$ & Roger Sessions & I995 & Jonathan Harvey \\
\hline I968-69 & Gerald Abraham & 1997 & Lydia Goehr \\
\hline I970-7I & Leonard B. Meyer & 1998 & Izaly Zemtsovsky \\
\hline I972 & Edward T. Cone & 1999 & David Huron \\
\hline I975-76 & Donald Jay Grout & 2002 & Roger Parker \\
\hline I977 & Charles Rosen & 2003 & Steven Stucky \\
\hline I979-80 & William Malm & 2005 & William Bolcom \\
\hline I980-8I & Alan Tyson & 2007 & Martha Feldman \\
\hline I980-8I & Andrew Porter & 2008 & Steve Mackey \\
\hline 1983 & Ton De Leeuw & 2009 & Steven Feld \\
\hline 1983 & James Haar & 2010 & Pedro Memelsdorff \\
\hline 1985 & Richard Crawford & 2010 & Peter Franklin \\
\hline I986 & John Blacking & $20 I I$ & Fred Lerdahl \\
\hline 1987 & Gunther Schuller & 2013 & George E. Lewis \\
\hline 1989 & George Perle & 2013 & Martin Stokes \\
\hline 1989 & László Somfai & 2014 & Georgina Born \\
\hline
\end{tabular}


The publisher gratefully acknowledges the generous contribution to this book provided by the Otto Kinkeldey Endowment of the American Musicological Society. 
THE SECULAR COMMEDIA 


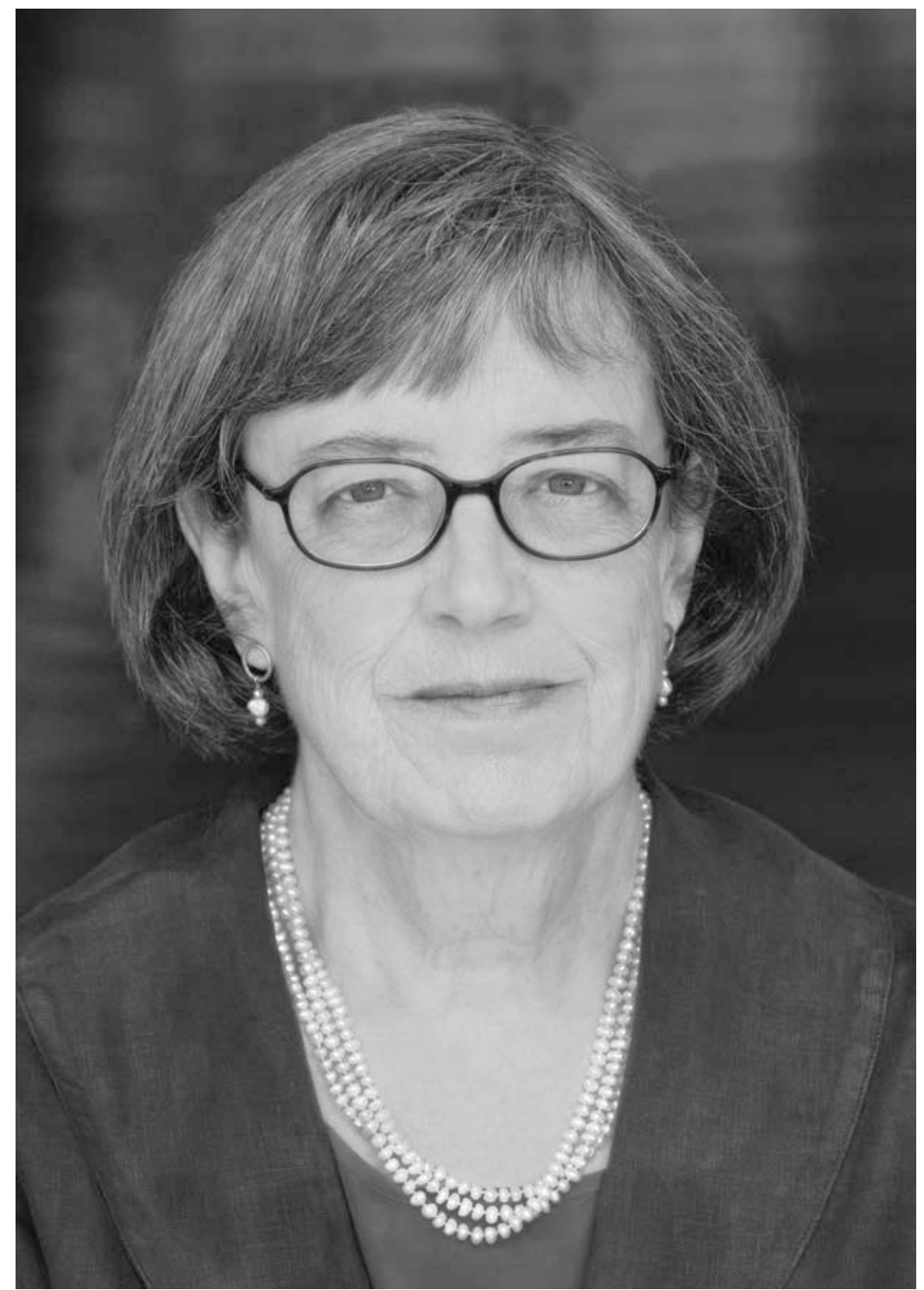

Wye Allanbrook in the Hargrove Library; she was an important part of the effort to get the library built. Photo by Kathleen Karn, UC Berkeley Department of Music. 


\section{THE SECULAR COMMEDIA}

COMIC MIMESIS IN LATE

EIGHTEENTH-CENTURY MUSIC

\section{Wye Jamison Allanbrook}

Edited by Mary Ann Smart and Richard Taruskin

曰 UNIVERSITY OF CALIFORNIA PRESS 
University of California Press, one of the most distinguished university presses in the United States, enriches lives around the world by advancing scholarship in the humanities, social sciences, and natural sciences. Its activities are supported by the UC Press Foundation and by philanthropic contributions from individuals and institutions. For more information, visit www.ucpress.edu.

University of California Press

Oakland, California

(C) 2014 by The Regents of the University of California

Library of Congress Cataloging-in-Publication Data

Allanbrook, Wye Jamison.

The secular commedia : comic mimesis in late eighteenthcentury music / Wye Jamison Allanbrook ; edited by Mary

Ann Smart and Richard Taruskin.

pages cm.-(Ernest Bloch lecture series; 15 )

Includes bibliographical references and index.

ISBN 978-0-520-27407-5 (cloth : alk. paper)

ISBN 978-0-520-95887-6 (ebook)

I. Music-I8th century-History and criticism.

2. Music-I8th century-Philosophy and aesthetics.

3. Opera-18th century. 4. Comic, The, in music.

5. Mimesis in music. I. Smart, Mary Ann. II. Taruskin,

Richard. III. Title.

MLi95.A45 2014

$780.9^{\prime} 033-\mathrm{dc} 23$

2014004820

Manufactured in the United States of America

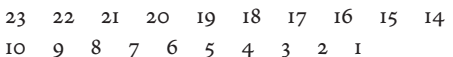

In keeping with a commitment to support environmentally responsible and sustainable printing practices, UC Press has printed this book on Natures Natural, a fiber that contains $30 \%$ post-consumer waste and meets the minimum requirements of ANSI/NISO Z39.48-I992 (R 1997) (Permanence of Paper). 